\title{
The Relationship between Political Orientation and Race on Modern Racism
}

\author{
David Bryan Oxendine (Corresponding author) \\ University of North Carolina at Pembroke, USA \\ E-mail: david.oxendine@uncp.edu
}

Received: June 30, 2015 Accepted: August 15, 2015 Published: August 16, 2015

doi:10.5296/jsss.v3i1.7933 URL: http://dx.doi.org/10.5296/jsss.v3i1.7933

\begin{abstract}
Political orientation and race have consistently found to be associated with attitudes leading to the foundational elements underpinning prejudice. This study investigates these relationships more fully in order to determine the magnitude of these relationships leading to modern racist attitudes. The research participants consisted of 225 undergraduate and graduate students at an ethnically diverse regional university in the southeastern United States. Consistent with existing literature, White participants reported greater levels of modern racist attitudes than did Non-White participants. As hypothesized, political orientation and race significantly related to modern racist attitudes. Implications for continuing future research on political orientation, race and other factors associated with modern racism.
\end{abstract}

Keywords: Political orientation, Race, Modern racism, Racist attitudes 


\section{Introduction}

After President Barack Obama's election in 2008 news outlets signaled the end of racism 145 years after the Emancipation Proclamation. Today anyone that picks up a newspaper or watches network and cable news outlets are clearly aware of the apparent current racial or prejudicial unrest due to encounters between the police and Black males. Recently, in Charleston, South Carolina a young White male opened fire in a well-known African American church killing nine parishioners, including the pastor after declaring he was going to kill Black people.

For more than half a century social psychologists have considered and studied the basic tenets of racism and prejudice to uncover why some individuals are more prejudiced and harbor more racist attitudes and others do not (Allport, 1954; Nelson, 2006; Utsey, Ponterotto, \& Porter, 2008; West, Pearson, Dovidio, Johnson, \& Phills, 2014). Racism, consistently related directly to prejudice, transcends a simple correlation to include an underlying belief system that has as its primary objective, to make submissive, dominate, and control members of other racial groups. The social psychological literature consistently reports that political orientation and racial group membership is significantly related to modern racist attitudes (Allport, 1954; Guimond, Crisp, Oliveira, Kamiejski, Kteily, Kuepper, Lalonde, Levin, Pratto, Tougas, Sidanius, \& Zick, 2013; Nelson, 2006; West et al., 2014).

\subsection{Political Orientation}

Political orientation, although, controversial at times, has been the focus of numerous research studies investigating political conservatism and its relationship with modern racist attitudes (Nail, Harter, \& Decker, 2003; Nelson, 2006; Pratto, Sidanius, Stallworth, \& Malle, 1994). A considerable number of studies have shown that political orientation has a significant relationship with modern racist attitudes (Guimond et al., 2013; Nail et al., 2003; Nelson, 2006; Sniderman, Piazza, Tetlock, \& Kendrick, 1991; Whitley, 1999).

There is consistent empirical data supporting conservatives, for the most part, oppose civil rights legislation such as affirmative action policies out of concern that such policies would create an environment where employers would resort to hiring quotas for women and minorities. Conservatives argue that this principled conservatism model works to prevent racial inequality and create a color-blind society (Sidanius, Pratto, \& Bobo, 1996). They also deny that their concern is not motivated by prejudice and racism but for fairness. According to Whitley and Kite (2006), the endorsement of conservative political ideologies and racial prejudice support these particular correlations. In addition, the concept and support of political-economic conservatism correlates to capitalist verses socialist political ideologies.

A major component of this phenomenon is Social Dominance Orientation (SDO), where an individual or group desires their in-group to dominate and be superior to out-groups (Akrami \& Ekehammar, 2006; Guimond, Dambrun, Michinov, \& Duarte, 2003; Sidanius \& Pratto, 2004; Snellman \& Ekehammar, 2000). In other words, societies reduce group conflict within communities by shaping ideologies that maintain superiority of one group over another. SDO suggests as a significant factor the extent to which in-groups feel they deserve to dominate 
and are superior to out-groups.

Based on Dovidio and Gaertner's (1986) model of symbolic-racism and modern racism links between political conservatism and symbolic-racism, and political liberalism and aversive racism has advanced. Symbolic-racism is the melding of anti-Black affect (generally politically conservative) and traditional American values, adopting "political correctness" and not expressing their prejudiced beliefs in public settings. Conversely, aversive racism in political liberals have adopted and internalized non-prejudiced values and social norm striving for a more inclusive society, while maintaining latent negative affect toward minorities (Nail et al., 2003). Dovidio and Gaertner found that political conservatives have done very little to adjust and evolve their personal attitudes and beliefs and have not realized while others have made adjustments they have failed to understand what is appropriate and what is not.

Research continues to show that most people make efforts to be "less prejudiced" and do not respond to racial stimuli. However, abundant research suggests a large percentage of the population continue to hold modern racist attitudes (Cokely, Tran, Hall-Clark, Chapman, Bessa, Finley, \& Martinez, 2010; Lee, 2005; McConahay, 1986; Sydell, Lilly, Duran, Lee, \& Browne, 2000; Sydell, Spanierman, \& Doan, 2006; Ponterotto, Burkand, Rieger, Grieger, D’Onofrios, Dubusison, Heenehan, Millstein, Parisi, Rath, \& Sax, 1995). According to Sniderman, Piazza, Tetlock, and Kendrick (1991), conservative groups were more likely than are liberals, to deny government assistance to Blacks if their perception was that they broke traditional values or did not behave, as they should. However, if Black individuals followed traditional values or behaved as expected, they may qualify for government assistance. This has evolved and internalized political orientation embellished with deep-rooted emotional personal meaning that any threat to this ideology maybe viewed as a personal attack (Nail et al., 2003). The principled conservatism model operationalizes in this fashion with White Americans on one hand supporting completely the principle of racial equality and simultaneously, on the other hand, displaying consistent opposition of policies that would appear to rectify and overturn racial inequality (Sidanius et al., 1996). Interwoven within these complex belief and value systems are racial prejudice and cultural elitism. Racial prejudice is the notion the perception of relative group status derives from on racial group membership (Pratto et al., 1994).

\subsection{Race}

The $20^{\text {th }}$ century has witnessed an enormous shift in race relations in the United States. This shift from blatant and aggressiveness to covert and subdued, credited mainly to the Civil Rights movement in the 1960s creating various approaches in order to research this shift accurately (Sydell \& Nelson, 2000). The psychological sciences have a long and controversial history in its attempts to measure and explain human variation and population differences (Smedley \& Smedley, 2005). Over the years, the literature has abundant studies that suggest and advance the argument that racial group variations on measures such as intelligence tests demonstrate that genetics determine group differences not explained by socioeconomic and environmental differences. These results suggest to some psychologists 
that Africans and African descendants are genetically inferior to Europeans and European descendants (Smedley \& Smedley, 2005; Whitley \& Kite, 2006).

Racism is a cultural phenomenon that develops as early as the preschool years (Rothenberg, 2007). White's as a group, in the United States continue to greatly underestimate how widespread racial disparities are today (Dovidio, Gaertner, Kawakami, \& Hodson, 2002; Utsey et al., 2008). Socially, the United States is still composed largely of segregated communities (Bakanic, 2009; Bryan, Wilson, Lewis, \& Willis, 2012; Cokely et al., 2010; Gallagher, 2011; Jackson, 2011; Jones, 2002; Nelson, 2006; Rothenberg, 2007; Smedley \& Smedley, 2005).

\subsection{Modern Racism}

Following the civil rights movement of the 1960s and 1970s racist attitudes and beliefs shifted from being more blatant to more subtle and ambivalent (Brief, Dietz, Cohen, Pugh, \& Vaslow, 2000; Cokely et al., 2010; Jackson, 2011; McConahay, 1983, 1986). Classic racism was demonstrated by the pre-civil rights era attitudes toward Blacks and other minorities, for example businesses may tell their hiring managers to "lighten up" their sales people by reducing the number of Black employees or not placing Black employees where they interact with the public (Brief et al., 2000). Most social psychologists suggest that prejudice and racism operate at different levels at the individual, interpersonal, intergroup, and at the institutional levels (Augoustinos \& Reynolds, 2002; Jackson, 2011).

From the mid-late 1960s, the nature of prejudice and racism has evolved as well. Prejudicial attitudes and beliefs, although improved greatly, have morphed from blatant overt racial prejudice into racial prejudice that is covert, which today is referred to as modern racism (Augoustinos \& Reynolds, 2002; Brief et al., 2000; Cokely et al., 2010; Jackson, 2011). The implications of modern racism are that of a more indirect and rationalized behavior toward Blacks and other minorities where one's negative attitudes and behaviors cloaked with nonracial attitudes and behaviors to appear non-racist. According to McConahay (1986), modern racism has evolved into four areas: discrimination and racism as outdated and no longer an issue, the Black population is too aggressive with their demands, their demands are unfair, and perhaps most importantly, the gains by the Black population are undeserved as they are unqualified for some positions because of policies such as affirmative action.

The individual with modern racist attitudes view themselves as non-racists because they view there are empirical facts and they recognize racism as inherently bad (Brief et al., 2000). Oxendine (2004) found that individuals or groups that feel threatened by some form of social exclusion or devaluation over periods of time, cultures, and ethnic groups or gender become so deeply rooted these groups expect this type of treatment. Historically, Whites have viewed themselves as non-raced, which provides validation by the absence of color or raced speech in everyday language referring to themselves (Dyer, 2008).

Proponents of this approach rationalize their objection of such social policies like affirmative action because concern for equity and color-blindness as "reverse racism." It is now that political orientation and race intersect as modern racism. Therefore, this is one reason 
individuals with modern racist attitudes do not view themselves as racists because they rationalize a racist as someone with the more blatant or holding to more old-fashioned or historic racist attitudes. McConahay (1986) found multiple factors that correlate with modern racist attitudes including conservative political orientation, and demographics such as age, education, gender, and racial group.

\subsection{The Current Study}

The objective of the current inquiry seeks to examine the nature of modern racism and its relationship to political orientation and race. For simplicity, this study utilizes the broader term "racial group" differentiated as White and Non-White. The survey sample used in this study was comprised of university students with a large diverse ethnic student body as follows: American Indian 20.7\%, Asian/Pacific Island 1.7\%, Black 23.3\%, Hispanic 2.6\%, White $49.5 \%$, Other $1.3 \%$, and International $0.8 \%$ (White $=117$, Non-White=108).

\subsubsection{Hypotheses}

Hypothesis 1 states that there is a significant effect between political orientation (Republican) and modern racism resulting in higher levels of modern racist attitudes. Hypothesis 2 states that there is a significant effect between racial group (White) and modern racism resulting in higher levels of modern racist attitudes. Hypothesis 3 states that the participant's perception of the experimenter's racial group (White) membership will have a significant effect with modern racism mediating their responses with higher levels modern racist attitudes.

\section{Method}

\subsection{Participants}

Participants were 225 undergraduate and graduate college students (females $152=67.6 \%$ and males $73=32.4 \%$ ) enrolled at a small Southeastern university. The age range for the participants was as follows: $18-20=(n=54) 24 \%, 21-23=(n=87) 38.7 \%, 24-26=(n=23)$ $10.2 \%, 27-29=(n=15)(6.7 \%)$, and $30+=(n=46) 20.4 \%$.

\subsubsection{Demographics}

Participants indicated the degree of exposure to people of different races, estimated percentage of White friends, amount of multicultural education, religiosity, grade point average, relationship status, religious orientation and affiliation, political orientation, socioeconomic status, ethnicity, sex, age, and college classification.

\subsubsection{Political Orientation}

Political orientation was assessed in the traditional method (e.g., Sidanius et al., 1996) by having participants self-report their political orientation into these categories: Democrat $(n=$ 98) $43.6 \%$, Republican $(n=64) 28.4 \%$, Independent $(n=15) 6.7 \%$, Other $(n=10) 4.4 \%$, and None $(n=38) 16.9 \%$.

\subsubsection{Racial Group}

Racial group was assessed from participants self-reporting their racial group as follows: 


\section{Mll Macrothink}

American Indian $(n=49) 21.8 \%$, Black $(n=39) 17.3 \%$, Asian $(n=5) 2.2 \%$, Hispanic $(n=7)$ $3.1 \%$, White $(n=117) 52 \%$, and those identified as Other $(n=8) 3.6 \%$. This sample is representative of the university population. For the purposes of this study, Racial Group, for simplicity is the construct employed as reported by the participants (White $=117$, Non-White=108).

\subsubsection{Experimenter Racial Group}

The participants assessed the experimenter's racial group (White or Non-White) based on their perception of the experimenter's racial group membership. The uniqueness of this particular university's history, location, faculty, and student population racial group membership is often as simple as knowing surnames of individuals. In other words, the participant's perception of the experimenter's racial group mediates participant responses. Although, not scientific as such, participant perception of the experimenter's racial group is all that is required for the hypothesized effect. Each MRS was coded to identify which questionnaire was completed with a White or Non-White experimenter.

\subsubsection{Measures}

\subsubsection{Modern Racism Scale (MRS)}

McConahay's (1986) Modern Racism Scale is a 7-item instrument that measures racist attitudes. According to McConahay $(1983,1986)$, the MRS measures affective and cognitive relationships related to modern racism. The MRS is rated on a 5-point Likert type scale with $1=$ Strongly Disagree to $5=$ Strongly Agree. Higher scores reflect greater racist attitudes. Reliability analysis using Cronbach's alpha for the current study yielded a coefficient of .82 $(M=2.217, S D=0.890)$, which is consistent with McConahay's findings of Cronbach's alpha of .86. See the MRS questions in Table 1 below.

Table 1. Modern racism scale

1. Over the past few years, the government and news media have shown more respect to Blacks than they deserve

2. It is easy to understand the anger of Black people in America

3. Discrimination against Blacks is no longer a problem in the United States _..*

4. Over the past few years, Blacks have gotten more economically than they deserve

5. Blacks have more influence upon school desegregation plans than they ought to have

6. Blacks are getting too demanding in their push for equal rights

7. Blacks should not push themselves where they are not wanted

Note. *Item scored for Racism Denial subscale. $N=225$. Items scored on the following response choices ( $1=$ Strongly Disagree-5=Strongly Agree). Modern Racism Scale (MRS). 


\section{Results}

\subsection{Theoretical Predictions}

Pearson correlations obtained among the study variables political orientation and racial group confirmed significant relationships with modern racism. Most notably, political orientation and racial group significantly correlates with modern racist attitudes. See Table 2 for zero-order correlations between the study variables.

Table 2. Zero-Order correlations between study variables

\begin{tabular}{lllll}
\hline & \multicolumn{1}{c}{$P O$} & $R G$ & $E$ & $M R$ \\
\hline 1 & Political Orientation & -.155 & .105 & $.153^{* *}$ \\
2 & Racial Group & -.155 & -.065 & $-.139^{*}$ \\
3 & Experimenter & .105 & .065 & $-.137^{*}$ \\
4 & Modern Racism & $.153^{* *}$ & $.139 *$ & $.137^{*}$ \\
\hline
\end{tabular}

Note. ${ }^{*}$ Correlation is significant at the $p<.05$ level (2-tailed). $* *$ Correlation is significant at the $p<.01$ level (2-tailed). $N=225$. Modern Racism Scale (MRS).

To test Hypothesis 1 an ANOVA was conducted to better evaluate the relationship between political orientation and modern racism. This analysis revealed a significant result $F(4,220)$ $=3.121, p<.02, \mathrm{y}_{\mathrm{p}}{ }^{2}=.05$, which is a medium effect according to Cohen (1988). The observed power of the effect is .81; therefore, if a sample drawn from the population with an effect size equal to the effect size of this sample, there is an $80 \%$ chance of obtaining a significant result. A closer look at this relationship reveals Democrat $(M=2.118, \mathrm{SD}=.586)$, Republican $(M=2.351, S D=.567)$, and Independent $(M=2.533, S D=.747)$. Therefore, those participants that identified as Independent held significant greater levels of modern racist attitudes, followed closely by Republican participants, while Democrat participants reported the least levels of modern racist attitudes.

To test Hypothesis 2 and the relationship between racial group and modern racism an ANOVA was conducted. This analysis revealed a significant result $F(1,223)=4.376, p<.04$, $\mathrm{y}_{\mathrm{p}}{ }^{2}=.02$, which is a small effect according to Cohen (1988). The observed power of the effect is .55; therefore, if a sample drawn from the population with an effect size equal to the effect size of this sample, there is a $55 \%$ chance of obtaining a significant result. A closer look at this relationship reveals White group participants $(M=2.338, S D=.757)$ reported greater levels of modern racist attitudes than did Non-White group participants $(M=2.173$, $S D=.820)$.

According to McConahay (1986), MRS item 3 is a subscale representing racism denial. A follow up ANOVA was conducted to further evaluate the relationship between racism denial and racial group on modern racism. This analysis revealed a significant result $F(1,223)=$ 


\section{Macrothink}

22.624, $p<.0001, \mathrm{y}_{p}{ }^{2}=.09$, which is a large effect according to Cohen (1988). The observed power of the effect is .99; therefore, if a sample drawn from the population with an effect size equal to the effect size of this sample, there is a $99 \%$ chance of obtaining a significant result. A closer look at this relationship reveals the White group participants $(M=2.675, S D=.761)$ reported significantly greater levels of racism denial than did Non-White group participants $(M=2.166, S D=.843)$. This result appears to contradict the findings of Hypothesis 2 . The magnitude of the significance level of this analysis suggests that the racial group that believes racism is no longer an issue today also appears to be the racial group that holds greater levels of modern racist attitudes. These results support the principled conservatism model according to Sidanius et al. (1996).

In order to check the consistency of the findings for modern racist attitudes, an ANOVA was conducted to test Hypothesis 3, the impact of the perceived racial group of the experimenter. In other words, was there a difference among participants if the experimenter was perceived White $(n=42)$ or Non-White $(n=183)$. This analysis revealed a result $F(1,223)=4.248, p$ $<.04, \mathrm{y}_{\mathrm{p}}^{2}=.02$, which is a small effect according to Cohen (1988). The observed power of the effect is .54; therefore, if a sample drawn from the population with an effect size equal to the effect size of this sample, there is a $54 \%$ chance of obtaining a significant result. These results indicated that participants with a White experimenter reported greater levels of modern racist attitudes $(M=2.428, S D=.595)$ as compared to those with a Non-White experimenter $(M=2.220, S D=.591)$. These results are in Table 3 below.

Table 3. Experimenter X Racial Group ANOVA Means and Standard Deviations for Modern Racism

\begin{tabular}{lcccc}
\hline \multirow{2}{*}{ Experimenter } & \multicolumn{2}{c}{$\boldsymbol{P O}$} & \multicolumn{2}{c}{$\boldsymbol{R} \boldsymbol{G}$} \\
\cline { 2 - 5 } & $\boldsymbol{M}$ & $\boldsymbol{S D}$ & $\boldsymbol{M}$ & $\boldsymbol{S D}$ \\
\hline White & 2.501 & $(.608)^{*}$ & 2.381 & $(.622)^{*}$ \\
Non-White & 2.243 & $(.554)$ & 2.093 & $(.569)$ \\
\hline
\end{tabular}

Note. ${ }^{*} p<.05$ level. $N=225$. Items scored on the following response choices $(1=$ Strongly Disagree-5 = Strongly Agree). Modern Racism Scale (MRS).

The remainder of the means and standard deviations are as follows: political orientation (Democrat $n=98, M=2.111, S D=.586$; Republican $n=64, M=2.357, S D=.567$; Independent $n=15, M=2.533, S D=.747$; Other $n=10, M=2.371, S D=.632$; None $n=38$, $M=2.338, S D=.521$ ), racial group (White $n=117, M=2.338, S D=586$; Non-White $n=$ $108, M=2.173, S D=.595)$.

\section{Discussion}

The purpose of this study is to examine the nature of the relationship between political orientation and race with prejudice, modern racial attitudes, and beliefs. Among the leading theories of intergroup relations in social psychology, social identity theory, realistic group 
conflict theory, and social dominance theory all offer explanations to better understand modern racist attitudes (Guimond et al., 2013; Tajfel \& Turner, 1979; 1986).

All of these approaches emphasize the interaction of multiple cultural factors such as gender, political orientation, race, ethnicity, religion and sexual orientation have demonstrated through decades of research to creating environments for social conflict (Berryman-Fink, 2006; Cowan, 2005; Tropp, 2003). In order for intergroup contact to be, effective, racial groups must have a well-developed sense of their ethnic identity. This leads to a mutual understanding between various racial groups, thereby reducing prejudice. According to McConahay (1986), modern racists deny that racism exists, but they may have some deep-seated racist attitudes while striving to appear non-racist. In other words, modern racism exists under the radar in subtler, covert manifestations and actions.

Hypothesis 1 states that political orientation would have a significant impact on modern racist attitudes, which was supported. One's political orientation included in this model was determined to be a significant factor of modern racism. The ideologies of the major political parties (e.g. Democrats tend to be more liberal and Republicans more conservative) were accurately represented in this sample, therefore, these results for both racial group and political orientation as strong predictors of modern racist attitudes, is consistent with previous studies. For instance, political liberals would prefer equity and view unemployment and poverty as unfair, whereas political conservatives would prefer equity and view unemployment and poverty as fair ( $\mathrm{Ng} \&$ Allen, 2005).

Consistent with the literature, Hypothesis 2 was supported with White group participants reporting higher levels of modern racist attitudes as compared to Non-White group participants. A follow up analysis supported this finding by looking closer at racial group. A closer examination of the means suggest that White group $(M=2.338, S D=.586)$ participants have greater levels of modern racist attitudes than Non-White group $(M=2.173$, $S D=.595)$ participants supports this line of reasoning.

Analysis of the racism denial subscale of the MRS revealed on the surface what may appear as a contradiction, but on closer examination, it is very clear and supports the modern racism phenomena. These results revealed White group participants hold greater levels of modern racist attitudes, while at the same time deny that racism is an issue today. These findings demonstrate the invisible nature of modern racist attitudes, whereby, the same group that holds these attitudes is also the same group that vehemently rejects the notion that racism still exits. These findings suggest that many people in all sincerity and honesty truly believe they do not hold modern racist attitudes, but if the circumstances change or the question modified might reveal they might indeed harbor these attitudes and beliefs.

Hypothesis 3 states that perceived racial group (White or Non-White) of the experimenter is strongly associated with modern racist attitudes. Although SDO is not directly tested, based on the SDO literature, certain inferences may be drawn. According to SDO, defined as the desire that one's in-group dominate and be superior to out-groups, this manifestation appears to be quite strong in the White participants (Akrami \& Ekehammar, 2006; Guimond et al., 2003; Jackson, 2011; Pratto et al., 1994; Sidanius et al., 1996; Sidanius \& Pratto, 2004; 
Snellman \& Ekehammar, 2005). Numerous studies suggest that political conservatism significantly correlates with modern racist attitudes. The current findings are consistent with previous studies.

This finding is significant at many levels. These data suggest that individuals behave or react to their preconceived perception of the experimenter's race. This suggests that although the experimenter has assured the participants that their identity would remain anonymous and not linked to their responses on the questionnaires; respond to the degree they believe their answers remain anonymous. In other words, if they perceive the experimenter is White they are more likely to relax their inhibitions if they feel their responses match that of their perception of the experimenter. However, if they perceive the experimenter is Non-White, they appear guarded with their responses if they perceive those responses differ from their perception of the experimenter. It appears this behavior is a response to their perception of the experimenter in order to be viewed as non-racist.

Individuals high in SDO desire to maintain their superior position and strive to denigrate is members of out-groups and oppose equality enhancing social programs such as affirmative action and to discriminate against other out-group members in order to retain the status-quo (Guimond et al., 2003; Pratto et al., 1994; Sidanius \& Pratto, 2004; Snellman \& Ekehammar, 2005; Whitley, 1999; Whitley \& Kite, 2006). Although SDO was not assessed directly in the current study, these findings strongly suggest that an aspect of SDO, principle-implementation gap may explain the apparent contradiction whereby, White participants vocally support racial equality and at the same time appear to oppose policies that would strive for racial equality.

\subsubsection{Theoretical and Applied Implications}

The present study supports the theoretical significant relationship between political orientation and race on modern racism. Social dominance Orientation theory (SDO) states that individuals with conservative political beliefs tend to hold prejudice, modern racist attitudes, and beliefs toward Non-White individuals and groups (Nail et al., 2003; Nelson, 2006; Pratto et al., 1994; Sidanius et al., 1996).

From a theoretical perspective, the minimal significance of racial group in this particular sample might result from the above average diversity represented, specifically by Lumbee American Indian participants. The variance among the three groups is more equitable compared to most samples that are largely composed of White and Black participants. The Lumbee tribe of North Carolina is the largest tribe east of the Mississippi and the ninth largest in the United States (Sider, 1993, 2003). The university campus from which this sample was drawn may be unique as well. This university, which began, as an American Indian Normal School in 1887 to teach American Indians to become teachers, from the 1940s until 1953 was the only state, supported four-year American Indian serving college in the United States (Dial, 1993; Dial \& Eliades, 1996; Oxendine, 1995; Oxendine, 2004; Oxendine \& Nacoste, 2007; Sider, 1993, 2003; Wilkins, 2002).

SDO is a possible explanation for Hypothesis 2 and Hypothesis 3 (Akrami \& Ekehammar, 
2006; Snellman \& Ekehammar, 2005). Individuals high in SDO would discriminate against females even within the same racial or ethnic group. Social dominance focuses on people's desire to maintain the dominance of their in-group (in this case males), so their opposition may be motivated to maintain the distribution of benefits that are currently held by being a dominant figure in society, such as wealth, education, and employment (Whitley, 1999). Conversely, females tend to be more sensitive to social inequities. Future research should investigate whether SDO is a major contributing factor that demonstrates that males hold more prejudice, modern racist attitudes, and beliefs.

The sociohistorical context of the sample of this study plays an important role as well. This sample derives from a university community that has a long history of tri-racial (Lumbee American Indian, Black, and White) intergroup contact. This sociohistorical environment has created intergroup tensions throughout its history, which at times has intersected both the community and the university (Dial, 1993; Dial \& Eliades, 1996; Sider, 1993, 2003). Future research should replicate this study with a similar university population to determine exactly how influential the diverse ethnic environmental context of the present study had on the results.

\subsubsection{Limitations and Future Research}

As with any study, there are methodological limitations, which may limit any conclusions drawn from this study. Previous studies mainly used White and Black samples designed to measure modern racism attitudes from their White participants (Sydell et al., 2000; Sydell et al., 2006). This study attempted to access prejudicial, modern racist attitudes from a sample consisting of a large number American Indian participants in addition to White and Black participants. McConahay (1986) developed the MRS utilizing White participants and assessing prejudicial, attitudes, and beliefs as they relate to race, namely Black individuals. Since the sample in this study did not adhere to strictly to White participants, it is reasonable to consider the possibility that the diversity in this study could have a confounding affect with the results. One possible suggestion for future research could be to adopt the word minority for the word Black, by doing so may generalize and racial group more generic as opposed to White and Black. Furthermore, there does not appear a legitimate reason to discount the results in the present study. It is, however, important to acknowledge this possibility.

Another point of concern may be unequal gender numbers in the present study $(152=$ female, $73=$ male). In studies that may rely on gender for certain relationships to be viable this concern may be warranted. However, in this particular study, the impact of gender does not create a significant negative effect on the results.

Additionally, the MRS has not gone without criticism from other researchers according to Brief et al. (2000). That being stated, the existing literature, including the results from this study appear to support the use of the MRS as a valid and reliable nonreactive measure of prejudicial, modern racist attitudes, and beliefs.

Future research should investigate methods to adapt these measures to tap the various experiences of diverse populations. There could be slight differences because of employing a 
broad interpretation of groups as White and Non-White as stated earlier. Previous research suggests that most people because of advantage as opposed to disadvantage view prejudice, racism, and discrimination as White and Black issues even with clear understanding there are differences within and between racial and or ethnic groups.

One might question the generalizability external validity of this study with the use of students with issues of modern racist attitudes. Based on the existing results, it would appear to support the notion that college and university student populations mirror the greater population with differences only in magnitude and scale (Gassner \& McGuigan, 2014). Future research should investigate diverse populations and determine the relationship and other mediating variables may vary with an older, more mature population.

The present study explores relationship of political orientation and race as a function of modern racist attitudes. The results of this study support previous research finding significant relationships between modern racism and political orientation and race. This particular area of social psychological inquiry appear to be just as important and timely as it was decades ago during the civil rights debate in the 1960s. As stated earlier with presidential, gubernatorial, congressional elections in the near future, no doubt political orientation, and race will enforce below the surface as modern racism

\section{Acknowledgments}

Dr. David B. Oxendine, Associate Professor, Department of Elementary Education, School of Education, University of North Carolina at Pembroke. A Faculty Research Grant from the Teaching and Learning Center, at the University of North Carolina at Pembroke, in part supported this research. The author would like to thank Dr. Kevin Freeman, Associate Professor, Department of Political Science and Public Administration, the University of North Carolina at Pembroke for their assistance with data collection and preparation of this article. In addition, a special thanks to Dr. Rupert W. Nacoste Professor of Psychology at North Carolina State University for his guidance and assistance in the preparation of this article.

Correspondence concerning this article should be addressed to Dr. David B. Oxendine, School of Education at the University of North Carolina at Pembroke, P.O. Box 1510, Pembroke, N. C. 28372. E-mail: david.oxendine@uncp.edu.

\section{References}

Akrami, A., \& Ekehammar, B. (2006). Right-wing authoritarianism and social dominance Orientation. Their roots in big-five personality factors and facets. Journal of Individual Differences, 27(3), 117-126. http://dx.doi.org/10.1027/1614-0001.27.3.117

Allport, G. W. (1954). The nature of prejudice. Reading, MA: Addison-Wesley.

Augoustinos, M., \& Reynolds, K. J. (2002). Prejudice, racism, and social psychology. In M. Augoustino, \& K. J. Reynolds (Eds.), Understanding Prejudice, and Social Conflict (pp. 1-23). London: Sage Publications. 
Bakanic, V. (2009). Prejudice: Attitudes about race, class, and gender. New Jersey: Pearson.

Berryman-Fink, C. (2006). Reducing prejudice on campus: The role of intergroup contact in diversity education. College Student Journal, 40(3), 511-516.

Brief, A. P., Dietz, J., Cohen, R. R., Pugh, S. D., \& Vaslow, J. B. (2000). Just doing business: Modern racism and obedience to authority as explanations. Organizational behavior and Human, 81(1), 72-97. http://dx.doi.org/10.1006/obhd.1999.2867

Bryan, M. L., Lewis, B. S., Lewis, A. A., \& Willis, L. E. (2012). Exploring the impact of "race talk" in the education classroom: Doctoral student reflections. Journal of Diversity in Higher Education, 5(3), 123-137. http://dx.doi.org/10.1037/a0029489

Cohen, J. (1988). Statistical power analysis for the behavioral sciences $\left(2^{\text {nd }}\right.$ ed.). New Jersey: Lawrence Erlbaum Publishers.

Cokely, K. O., Tran, K., Hall-Clark, B., Chapman, C., Bessa, L., Finley, A., \& Martinez, M. (2010). Predicting student attitudes about racial diversity and gender equity. Journal of Diversity in Higher Education, 3(3), 187-199. http://dx.doi.org/10.1037/a0020467

Cowan, G. (2005). Interactions at racially diverse university campuses. The Journal of Social Psychology, 145(1), 49-63. http://dx.doi.org/10.3200/SOCP.145.1.49-64

Dial, A. L. (1993). The Lumbee. Indians of North America series. New York: Chelsea House.

Dial, A. L., \& Eliades, D. K. (1996). The Only Land I Know: A History of the Lumbee Indians. San Francisco, CA: Indian Historian Press. (Original work published 1975).

Dovidio, J. F., \& Gaertner, S. L. (1986). Prejudice, discrimination, and racism: Historical trends and contemporary approaches. In J. F. Dovidio, \& S. L. Gaertner (Eds.), Prejudice, Discrimination, and Racism (pp. 1-34). New York: Academic Press.

Dovidio, J. F., Gaertner, S. L., Kawakami, K., \& Hodson, G. (2002). Why can't we just get along? Interpersonal biases and interracial distrust. Cultural Diversity and Ethnic Minority Psychology, 8(2), 88-102.

Dyer, R. (2008). The matter of Whiteness. In. P. S. Rothenberg White privilege: Essential readings on the other side of racism ( $3^{\text {rd }}$ ed.) (pp. 9-14). New York: Worth Publishers.

Erikson, E. (1968). Identity: Youth and crisis. New York: Norton.

Gallagher, C. A. (2011). Rethinking the color line: Readings in race and ethnicity (5 ${ }^{\text {th }}$ ed.), New York: McGraw-Hill.

Gassner, B, \& McGuigan, W. (2014). Racial prejudice in college students: A cross-sectional examination. College Student Journal, 48(2), 249-256.

Guimond, S., Crisp, R. J., Oliveira, P. D., Kamiejski, R., Kteily, N., Kuepper, B., \& Zick, A. (2013). Diversity policy, social dominance, and intergroup relations: Predicting prejudice in changing social and political contexts. Journal of Personality and Social Psychology, 104(6), 941-958. http://dx.doi.org/10.1037/a0032069 
Guimond, S., Dambrun, M., Michinov, N., \& Duarte, S. (2003). Does social dominance generate prejudice? Integrating individual and contextual determinants of intergroup cognitions. Journal of Personality and Social Psychology, 84(4), 697-721. http://dx.doi.org/10.1037/0022-3514.84.4.697

Jackson, L. M. (2011). The psychology of prejudice: From attitudes to social action. Washington, D. C.: American Psychological Association. http://dx.doi.org/10.1037/12317-000

Lee, R. M. (2005). Resilience against discrimination: Ethnic identity and other-group Orientation as protective factors for Korean Americans. Journal of Counseling Psychology, 52(1), 36-44. http://dx.doi.org/10.1037/0022-0167.52.1.36

McConahay, J. B. (1983). Modern racism and modern discrimination: The effects of race, racial attitudes, and context on simulated hiring decisions. Personality and Social Psychology bulletin, 9(4), 551-558. http://dx.doi.org/10.1177/0146167283094004

McConahay, J. B. (1986). Modern racism, ambivalence, and the Modern Racism Scale. In J. F. Dovidio, \& S. L. Gaertner (Eds.), Prejudice, discrimination, and racism (pp. 61-89). Orlando, FL.: Academic Press.

Nail, P. R., Harton, H. C., \& Decker, B. P. (2003). Political Orientation and modern versus aversive racism: Tests of Dovidio and Gaertner's (1998) integrated model. Journal of $\begin{array}{lllll}\text { Personality } \quad \text { and } & \text { Social } & \text { 754-770. }\end{array}$ http://dx.doi.org/10.1037/0022-3514.84.4.754 PMid:12703647

Neville, H. A., Lilly, R. L., Duran, G., Lee, R. M., \& Browne, L. (2000). Construction and initial validation of the Color-Blind Racial Attitudes Scale (CoBRAS). Journal of Counseling Psychology, 47(1), 59-70. http://dx.doi.org/10.1037/0022-0167.47.1.59

Neville, H. A., Spanierman, L., \& Doan, B. T. (2006). Exploring the association between color-blind racial ideology and multicultural counseling competencies. Cultural Diversity and Ethnic Minority Psychology, 12(2), 275-290. http://dx.doi.org/10.1037/1099-9809.12.2.275

Nelson, T. D. (2006). The psychology of prejudice (2 ${ }^{\text {nd }}$ ed.). New York: Pearson.

Oxendine, D. (1995). Racial identity development among Lumbee American Indian college students on a predominately White campus. Unpublished master's thesis, North Carolina State University, Raleigh.

Oxendine, D. B. (2004). The effects of social exclusion threat and justifications on perceived fairness of an ethnic validation procedure: Implications for Lumbee Federal Recognition. (Doctoral dissertation, North Carolina State University, 2004). Dissertation Abstracts International, (UMI No. 3154343).

Oxendine, D. B., \& Nacoste, R. W. (2007). Who would claim to be that, who was not? Evaluations of an ethnic validation procedure. Journal of Applied Social Psychology, 37(7), 1594-1629. http://dx.doi.org/10.1111/j.1559-1816.2007.00229.x 
Ponterotto, J. G., Burkand, A., Rieger, B. P., Grieger, I., D’Onofrios, A., Dubusison, A., ... Sax, G. (1995, December). Development and initial validation of the Quick Discrimination Index (QDI). Educational and Psychological Measurement, 55(6), 1016-1031. http://dx.doi.org/10.1177/0013164495055006011

Pratto, F., Sidanius, J., Stallworth, L. M., \& Malle, B. F. (1994). Social dominance Orientation: A personality variable predicting social and political attitudes. Journal of $\begin{array}{lllll}\text { Personality } \quad \text { and } & \text { Social } & \text { 741-763. }\end{array}$ http://dx.doi.org/10.1037/0022-3514.67.4.741

Rothenberg, P. S. (2007). Race, class, and gender in the United States $\left(7^{\text {th }}\right.$ ed.). New York: Worth Publishers.

Sidanius, J. \& Pratto, F. (2004). Social Dominance: An Intergroup Theory of Social Hierarchy and Oppression. Cambridge, U. K.: Cambridge University Press.

Sidanius, J., Pratto, F., \& Bobo, L. (1996). Racism, conservatism, affirmative action, and intellectual sophistication: A matter of principled conservatism or group dominance? Journal of Personality and Social Psychology, 70(3), 476-490. http://dx.doi.org/10.1037/0022-3514.70.3.476

Sider, G. M. (1993). Lumbee Indian Histories: Race, Ethnicity, and Indian Identity in Southern United States. New York: Cambridge University Press.

Sider, G. M. (2003). Living Indian Histories: Lumbee and Tuscarora People in North Carolina. Chapel Hill: University of North Carolina Press.

Smedley, A., \& Smedley, B. D. (2005). Race as biology is fiction, racism as a social problem is real. American Psychologist, 60(1), 16-26. http://dx.doi.org/10.1037/0003-066X.60.1.16

Snellman, A. \& Ekehammar, B. (2005). Ethnic hierarchies, ethnic prejudice, and social dominance orientation. Journal of Community \& Applied Social Psychology, 15, 83-94. http://dx.doi.org/10.1002/casp.812

Sniderman, P. M., Piazza, T., Tetlock, P. E., \& Kendrick, A. (1991). The new racism. American Journal of Political Science, 35(2), 423-447. http://dx.doi.org/10.2307/2111369

Sydell, E. J., \& Nelson, E. S. (2000). Modern racism on campus: A survey of attitudes and perceptions. The Social Science Journal, 37(4), 627-635. http://dx.doi.org/10.1016/S0362-3319(00)00105-1

Tajfel, H., \& Turner, J. C. (1979). An integrative theory of intergroup relations. In W. G. Austin, \& S. Worchel (Eds.) The Social Psychology of Intergroup Relations. (pp. 33-47). Montrerey, CA: Brooks/Cole.

Tajfel, H., \& Turner, J. C. (1986). The social identity theory of intergroup behavior. In S. Worchel, \& W. G. Austin (Eds), Psychology of Intergroup Relations (2 ${ }^{\text {nd }}$ ed., pp. 7-24). Chicago: Nelson-Hall.

Utsey, S. O., Ponterotto, J. G., \& Porter, J. S. (2008). Prejudice and racism, year 2008-still 


\section{Macrothink}

Journal of Social Science Studies

ISSN 2329-9150

2016, Vol. 3, No. 1

going strong: Research on reducing prejudice with recommended methodological advances. Journal of Counseling and Development, 86(3), 339-347. http://dx.doi.org/10.1002/j.1556-6678.2008.tb00518.x

West, T. V., Pearson, A. R., Dovidio, J. F., Johnson, B. T., \& Phills, C. E. (2014). Racial attitudes and visual cues in political judgments: Support for Obama during the 2008 presidential election. Cultural Diversity and Ethnic Minority Psychology, http://dx.doi.org/10.1037/a0036947

Whitley, B. E., Jr. (1999). Right-wing authoritarianism, social dominance Orientation, and prejudice. Journal of Personality and Social Psychology, 77(1), 126-134. http://dx.doi.org/10.1037/0022-3514.77.1.126

Whitley, B. E., Jr., \& Kite, M. E. (2006). The psychology of prejudice and discrimination. CA: Thomson Wadsworth.

Wilkins, D. E. (2002). American Indian politics and the American political system. New York: Rowman and Littlefield Publisher, Inc.

\section{Copyright Disclaimer}

Copyright reserved by the author(s).

This article is an open-access article distributed under the terms and conditions of the Creative Commons Attribution license (http://creativecommons.org/licenses/by/3.0/). 